\title{
Determination of heavy metals concentration in drinking water of Potiskum Metropolitan, North Eastern, Nigeria
}

\author{
Muhammad Dahiru Audu ${ }^{1 *}$, Madu Mamman Maianguwa1', Ibrahim Gana Geidam² \\ ${ }^{1}$ Department of Physics, Federal College of Education (Tech), Potiskum, Nigeria \\ ${ }^{2}$ Department of Physics, Yobe State University Damaturu, Nigeria \\ *Corresponding author: mdabdulpot29@gmail.com
}

DOI : https://doi.org/10.37134/ejsmt.vol7.2.4.2020

Received: 29 May 2020; Accepted: 20 July 2020; Published: 28 August 2020

Cite this article (APA): Audu, M. D., Maianguwa, M. M., \& Geidam, I. G. (2020). Determination of heavy metals concentration in drinking water of Potiskum Metropolitan, North Eastern, Nigeria. EDUCATUM Journal of Science, Mathematics and Technology, 7(2), 31-39. https://doi.org/10.37134/ejsmt.vol7.2.4.2020

\begin{abstract}
The mean concentrations of heavy metals (HMs) such as Lead $(\mathrm{Pb})$, Cadmium $(\mathrm{Cd})$, Zinc $(\mathrm{Zn})$, and Iron $(\mathrm{Fe})$ in drinking water of Potiskum metropolitan were investigated. The water samples were collected from the following locations; ARK, PMP, MMD, ABB, NHT, FCE, and JGW. The sample's physic-chemical parameters such as $\mathrm{pH}$, Temperature, and Conductivity were analyzed using Atomic Absorption Spectrometer (AAS). The $\mathrm{pH}$ result for the three sample locations ABB (9.6), PMP (9.2), and JGW (8.8) was recorded and found to be above the recommended value set by Standard Organization of Nigerian (SON). Meanwhile, there Conductivities values were reported to be below the limit value $(1 \mathrm{~ms} / \mathrm{cm})$ set by SON. The results obtained the highest mean concentration of cadmium was recorded in FCE $(0.004 \pm 0.01 \mathrm{ppm})$ and observed above the recommended value set by $\mathrm{WHO}(0.003 \mathrm{ppm})$, the highest mean concentration of lead was found in FCE $(0.090 \pm 0.012 \mathrm{ppm})$ and all mean concentrations of lead were recorded above the recommended values set by $\mathrm{WHO}(0.01 \mathrm{ppm})$ and $\mathrm{SON}(0.01 \mathrm{ppm})$, the highest concentration of zinc was recorded in JGW $(0.024 \pm 0.026 \mathrm{ppm})$ and all sampling points have recorded the concentrations of zinc below the recommended value set by WHO(5.0ppm) and SON(3.0ppm). The highest mean concentration of iron was recorded in ARK $(0.310 \pm 0.063 \mathrm{ppm})$ and all sampling points have recorded the concentrations of iron below the recommended value set by SON (0.3ppm) except ARK (recorded above).
\end{abstract}

Keywords: Heavy Metals, Potiskum Metropolitan, Drinking water, Atomic Absorption Spectrometer

\section{INTRODUCTION}

Assessment of the level of heavy metals (e.g., Lead, Cadmium, Zinc, and Iron) in our immediate environment, human body, drinking water, and any matter that has a direct relation with our health status is very essential. Heavy metals simply refer to metals whose density is greater than $4 \mathrm{~g} / \mathrm{cm}^{-3}[1,2]$. Water is requisite for community and human survival and is the most crucial aspect of our life [3]. Sources of natural Water were categorized into groundwater (borehole, hand-dug, etc.), rainwater, and surface water [4]. It is necessary to protect our water sources from contaminants because metals existing in drinking water and all natural water constituted a mixture of organic and inorganic chemicals [5]. Therefore, in many countries, be it developed, developing, and industrialized or high tech nations have regulatory agencies (for instance WHO, UNICEF, US EFA\& SON). However, one of the basic goals of WHO and its affiliate states is that "all people, whatever their stage of development and their social and economic conditions, have the right to have access to an adequate supply of safe drinking water" [6]. Thus, these agencies are responsible for providing or established the guidelines value derivation of drinking water.

Several studies hold the view that heavy metals are harmful to human health, Animals and environment [7-10. In terms of carcinogenic effect, too much zinc in drinking-water yielded a sarcoma [6]. Another side effect on humans according to one study reported that exposure to zinc fumes yielded the following symptoms: 
pulmonary distress, fever, gastroenteritis, and chills [11. Inhalations of cigarette smoke, ingestion of contaminated foods, working in metal industries, and employment in cadmium - contaminated workplaces are major ways of human exposure to cadmium [12]. Cadmium is harmful heavy metals that lead to death if inhaled because it is a severe pulmonary and abdominal pain $[12,13]$. Another study confessed that cadmium is classified as a human carcinogen $[14,15]$. Lead with concentration more than $15 \mathrm{ppb}$ over long periods can lead to health problems [16]. Another report shows that the lead in drinking water increases the risk of cancer diseases [16, 17]. This carcinogenic effect was confirmed by the International Agency for Research on Cancer [18]. Iron is one of the most abundant elements in the earth's crust. Iron may be found in drinking water at a concentration up to several milligrams per liter without discoloration. However, the World health organization is silent on healthbased guideline value for iron [5]. But another report showed that long- period of inhalation of iron fumes can lead to siderosis - a lung condition showing changed in respiration rates and pneumoconiosis and similarly for the same report indicated that for drinking water the case of aesthetic effects such as taste may occur and ingestion of toxic levels of iron for infants and young children can cause damage of blood vessels, kidney, liver, and result in death [19].

Many studies recommended the use of Atomic absorption spectrometry to determine the heavy metals in water [20-24]. In the study of the "evaluation of heavy metals concentration in drinking water collected from wells and boreholes of Dutse town, Northwest, Nigeria." using atomic absorption spectrometer, they found that some metals such as cadmium $(\mathrm{Cd}=0.0034 \mathrm{mg} / \mathrm{l})$, Copper $(\mathrm{Cu}=0.0151 \mathrm{mg} / \mathrm{l})$ and Nickel $(\mathrm{Ni}=0.0433 \mathrm{mg} / \mathrm{l})$ were below recommended level while other metals such as lead $(\mathrm{Pb}=0.0151 \mathrm{mg} / \mathrm{l})$, Iron $(\mathrm{Fe}=1.8241 \mathrm{mg} / \mathrm{l})$ were above the recommended values established by USEPA and WHO. Moreover, similar analytical approach for the study of "Heavy Metals (Cd, Cu, Fe, Mn, and Zn,), assessment of groundwater, in Kaltungo LGA, Gombe State, Nigeria" the following results were reported ranges for Copper $(0.03-0.60 \mathrm{mg} / \mathrm{l})$, iron $(0.395-22.90 \mathrm{mg} / \mathrm{l})$, zinc (0.073-1.670 mg/l), manganese (0.046-1.85 mg/l) and cadmium (0.009-0.446 mg/l). Cadmium, manganese, and iron in many samples exceeded the WHO recommended values [25].

Potiskum being a commercial nerve and most populous town of Yobe state is experiencing a regular influx of people from various parts of Nigeria due to increased commercial activities such as mechanic workshops, welding workshops, Blacksmith activities, etc. The people of Potiskum metropolitan relayed heavily on wells and Boreholes water as their major sources of drinking water for a livelihood without undergoing any treatment. Therefore, the cases of diseases such as prostate cancer, renal tumor, cognitive decline, cardiovascular diseases in adults are common in the metropolitan. There was no documented literature on the level of heavy metals present in the drinking water of the Potiskum metropolitan. This study aim to determine the level of the mean concentration of heavy metals, and physiochemical properties such as $\mathrm{PH}$, Conductivity in groundwater of some selected locations in Potiskum using an Atomic Absorption Spectrometer.

\section{MATERIALS AND METHODS}

\section{Study Area}

Potiskum is a local government area in Yobe state, Nigeria on the A3 highway at $11^{0} 43^{\prime} \mathrm{N} 11^{0} .04^{\prime} \mathrm{E}$. It has an area of 559 square kilometers (216 Sqmi) with a population of about 205, 876 at 2006 census. GMT in Potiskum is plus one $(+1)$ hour and is located in a semi-arid region of Nigeria with a tropical continental climate which is characterized by the short wet season, i.e. from June to August and annual rainfall i.e. low with an average of $500-1000 \mathrm{~mm}$, where the dry season is long i.e. from October to May, with a high temperature of about $38{ }^{\circ} \mathrm{C}$ to $44^{\circ} \mathrm{C}$ annually. Potiskum is the largest city in Yobe state with a booming business. It has one of the largest cattle markets in West Africa. Table 1 shows the coordinates of the study sites. 
Table 1: Show the coordinates of the study sites of Potiskum metropolitan

\begin{tabular}{lll}
\hline & \multicolumn{3}{c}{ Coordinates } \\
Sample Pointes & Latitude & Longitude \\
& & \\
\hline FCE & $11^{\circ} 42^{\prime} 23.1^{\prime \prime} \mathrm{N}$ & $11^{\circ} 4^{\prime} 9.3^{\prime \prime} \mathrm{E}$ \\
MMD & $11^{\circ} 42^{\prime} 22.1^{\prime \prime} \mathrm{N}$ & $11^{\circ} 4^{\prime} 9.4^{\prime \prime} \mathrm{E}$ \\
NHT & $11^{\circ} 42^{\prime} 22.9^{\prime \prime} \mathrm{N}$ & $11^{\circ} 4^{\prime} 8.4^{\prime \prime} \mathrm{E}$ \\
ARK & $11^{\circ} 42^{\prime} 23.3^{\prime \prime} \mathrm{N}$ & $11^{\circ} 4^{\prime} 8.5^{\prime \prime} \mathrm{E}$ \\
PMP & $11^{\circ} 42^{\prime} 23.2^{\prime \prime} \mathrm{N}$ & $11^{\circ} 4^{\prime} 7.9^{\prime \prime} \mathrm{E}$ \\
ABB & $11^{\circ} 42^{\prime} 27.5^{\prime \prime} \mathrm{N}$ & $11^{\circ} 3^{\prime} 27.5^{\prime \prime} \mathrm{E}$ \\
JGW & $11^{\circ} 42^{\prime} 23.1^{\prime \prime} \mathrm{N}$ & $11^{\circ} 4^{\prime} 8.6^{\prime \prime} \mathrm{E}$ \\
\hline
\end{tabular}

\section{Procedure of Sample Collection}

One liter High density polyethylene container (HDPC) as sample containers and their caps were rinsed three times with deionized water. To avoid contaminates (water being highly mobile) the water was allowed to flow for 2 minutes and then the sample containers were filled with one to two inches from the top. The samples were preserved at the sampling point with nitric acid $\left(\mathrm{NHO}_{3}\right)$ to $\mathrm{pH}<2$ [26]. The samples were labeled using masking tape and transported to the laboratory for further analysis.

\section{Instrumentations}

In the instrumentation, AAS (Shimadzu: Model-6800, Japan) with a high-resolution continuum source was used. The method was based on the proper wavelength as listed in Table 2. All instrumental settings were adopted from the manufacturer's operation manual book. For $\mathrm{pH}$ a digital $\mathrm{pH}$ meter (Hannan 211 India) equipped with a glass electrode and temperature probe was used and also conductivities were measured using a digital conductivity meter (Hannan EC 215 India).

Table 2: The Instrumental Settings for the Flame Atomic Absorption Spectrometer (AAS-6800)

\begin{tabular}{|c|c|c|c|c|}
\hline \multirow{2}{*}{ Parameters Cadmi } & \multicolumn{2}{|c|}{ Lead $(\mathbf{P b})$} & Iron $(\mathbf{F e})$ & \multirow[t]{2}{*}{ Zinc (Zn) } \\
\hline & & & & \\
\hline Wavelength(nm): & 228.8 & 283.3 & 248.3 & 213.9 \\
\hline Lamp current $\operatorname{low}(\mathrm{mA})$ : & 8 & 20 & 12 & 10 \\
\hline Lamp current High(mA): & 100 & - & 400 & 300 \\
\hline Socket \# : & 1 & 3 & 5 & 2 \\
\hline Slit width(nm): & 1.0 & 1.0 & 0.2 & 0.5 \\
\hline Lamp mode: & BGC-SR & BGC-D2 & BGC-SR & BGC-SR \\
\hline \multicolumn{5}{|l|}{ Atomizer/Gas flow rate; } \\
\hline Fuel Gas flow rate(L/min): & 1.8 & 2.0 & 2.2 & 2.0 \\
\hline Flame type: & Air- C2H2 & Air- C2H2 & Air- C2H2 & Air- C2H2 \\
\hline Burner High(mm): & 7 & 7 & 9 & 7 \\
\hline \multicolumn{5}{|l|}{ Measurement parameter; } \\
\hline Concentration Unit: & ppm & ppm & ppm & ppm \\
\hline
\end{tabular}




\section{Instrument calibrations}

The Flame Atomic Absorption Spectrometer (AAS-6800) showed linear calibration curve and the linearity was evaluated with standard solutions at a concentration range of 0.0, 2.0, 4.0, and $6.0 \mathrm{ppm}$ for lead $\mathrm{Pb}(\mathrm{r}=0.998)$, cadmium $(\mathrm{Cd}) 0.00,0.10,0.30,0.50 \mathrm{ppm}(\mathrm{r}=0.9994)$, zinc $(\mathrm{Zn}) 0.00,0.10,0.30,0.50 \mathrm{ppm}(\mathrm{r}=0.9931)$, and iron $(\mathrm{Fe})$ 5.0, 10.0, 15.0, 20.0, $25.0 \mathrm{ppm}(\mathrm{r}=0.9962)$.

\section{RESULT}

The mean concentrations with a standard deviation of lead $(\mathrm{Pb})$, cadmium $(\mathrm{Cd})$, iron $(\mathrm{Fe})$, and $\mathrm{Zinc}(\mathrm{Zn})$ and Physico-Chemical properties of drinking water samples of Potiskum metropolitan were presented in Table 3 and figure 1 respectively.

Table 3: Mean ( \pm SD) Concentrations of heavy metals (in ppm) of Drinking water of Potiskum metropolitan.

\begin{tabular}{lllll}
\hline $\begin{array}{l}\text { Sampling } \\
\text { Points }\end{array}$ & $\begin{array}{l}\text { Mean Lead Conc. } \\
(\mathrm{ppm})\end{array}$ & $\begin{array}{l}\text { Mean Cadmium Conc. } \\
(\mathrm{ppm})\end{array}$ & $\begin{array}{l}\text { Mean Iron Conc. } \\
(\mathrm{ppm})\end{array}$ & $\begin{array}{l}\text { Mean Zinc Conc. } \\
(\mathrm{ppm})\end{array}$ \\
\hline ABB & $0.065 \pm 0.02$ & $0.003 \pm 0.001$ & $0.071 \pm 0.013$ & $0.004 \pm 0.001$ \\
MMD & $0.048 \pm 0.015$ & $0.002 \pm 0.001$ & $0.102 \pm 0.018$ & $0.004 \pm 0.000$ \\
FCE & $0.090 \pm 0.012$ & $0.004 \pm 0.001$ & $.0098 \pm 0.074$ & $0.004 \pm 0.001$ \\
PMP & $0.087 \pm 0.021$ & $0.003 \pm 0.002$ & $0.017 \pm 0.027$ & $0.002 \pm 0.001$ \\
ARK & $0.056 \pm 0.004$ & $0.001 \pm 0.001$ & $0.310 \pm 0.063$ & $0.010 \pm 0.002$ \\
JGW & $0.058 \pm 0.015$ & $0.002 \pm 0.007$ & $0.034 \pm 0.093$ & $0.024 \pm 0.026$ \\
NHT & $0.082 \pm 0.018$ & $0.002 \pm 0.001$ & $0.054 \pm 0.005$ & $0.016 \pm 0.022$ \\
\hline
\end{tabular}

ABBREVIATIONS: ABB: Alhaji Barau Brigde Potiskum, MMD: Mamudo, FCE: Federal College of Education (technical) Potiskum, PMP: Potiskum Main Motor Pack (Sabon Tasha), ARK: Arikime Potiskum, JGW: Jigawa Potiskum, NHT: Nahuta.

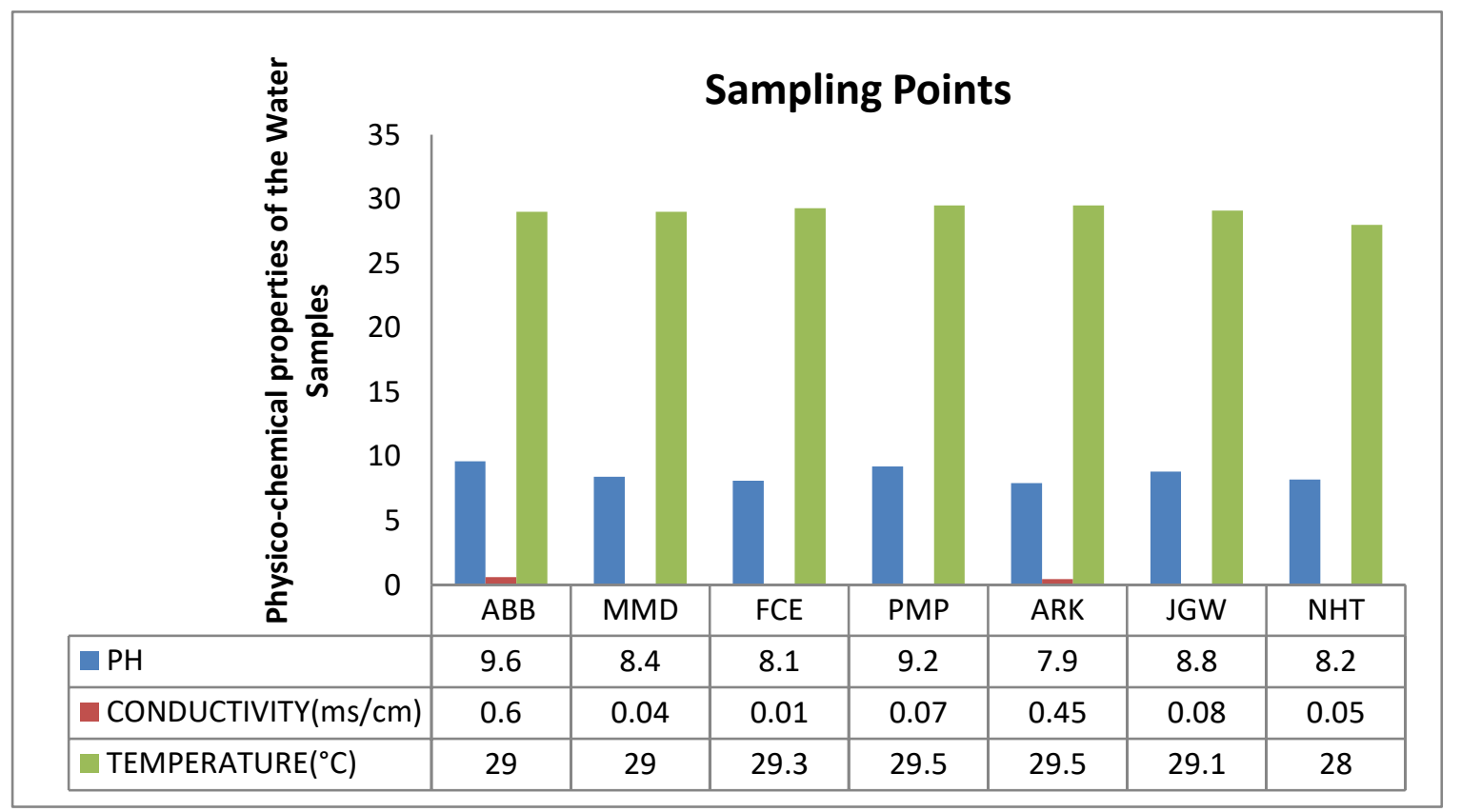

Figure 1: Physico-chemical properties of the drinking water of Potiskum metropolitan. 
Table 4: Guideline values for the recommended level of studied heavy metals in ppm

\begin{tabular}{lll}
\hline Parameters (Unit) & WHO Guideline values & SON Guideline value \\
\hline Cadmium ( ppm) & 0.003 & 0.003 \\
Lead ( ppm) & 0.01 & 0.01 \\
Iron ( ppm) & NH & 0.3 \\
Zinc ( ppm) & 5 & 3 \\
PH & NH & $6.5-8.5$ \\
Conductivity $(\mathrm{ms} / \mathrm{cm})$ & - & 1 \\
\hline
\end{tabular}

*NH means "not of health concerns at a level found in drinking water", World Health Organization [5] and Standard Organization of Nigerian [27].

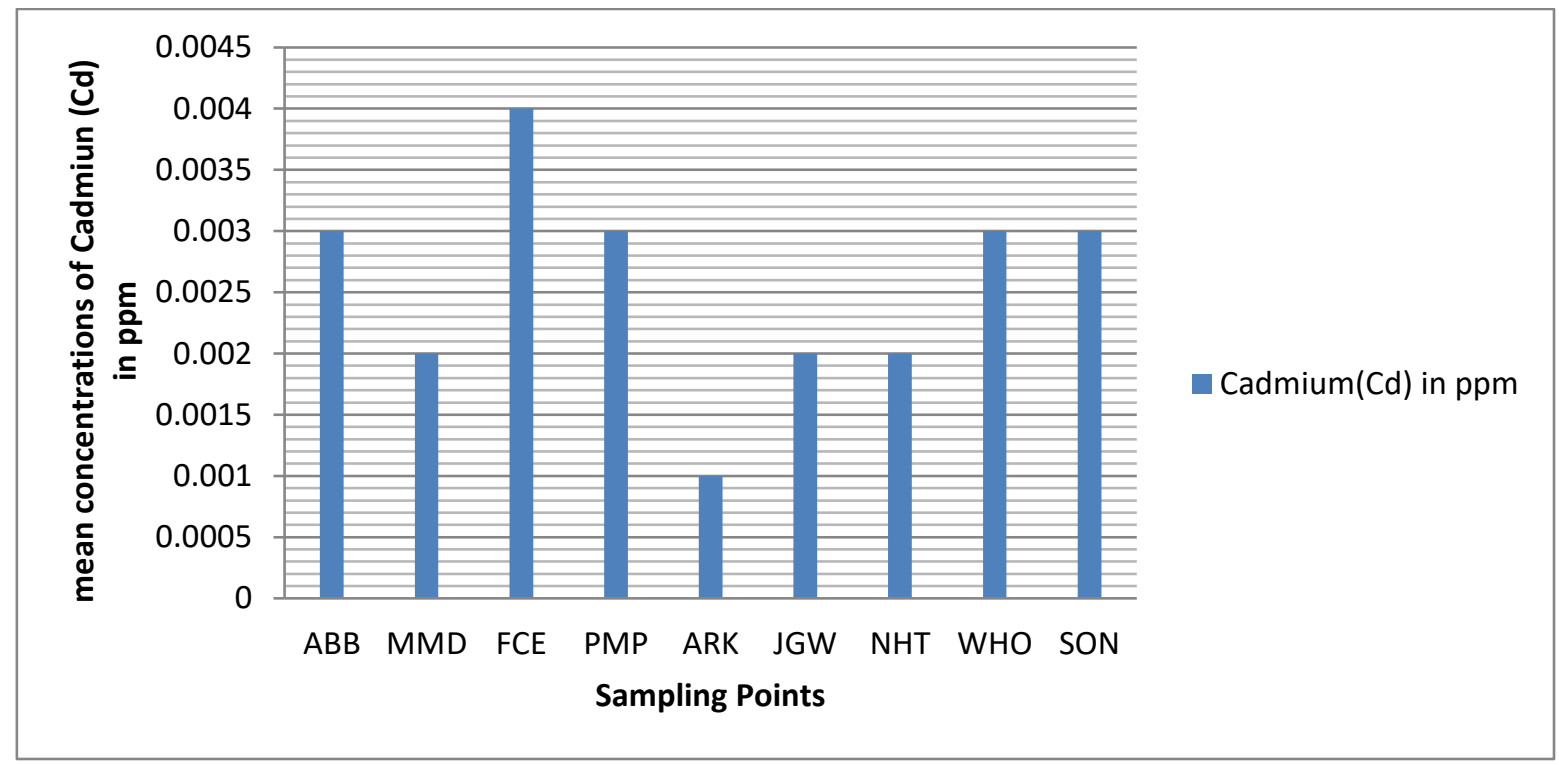

Figure 2: Mean Concentrations of Cadmium $(\mathrm{Cd})$ in Drinking Water of Potiskum Metropolitan.

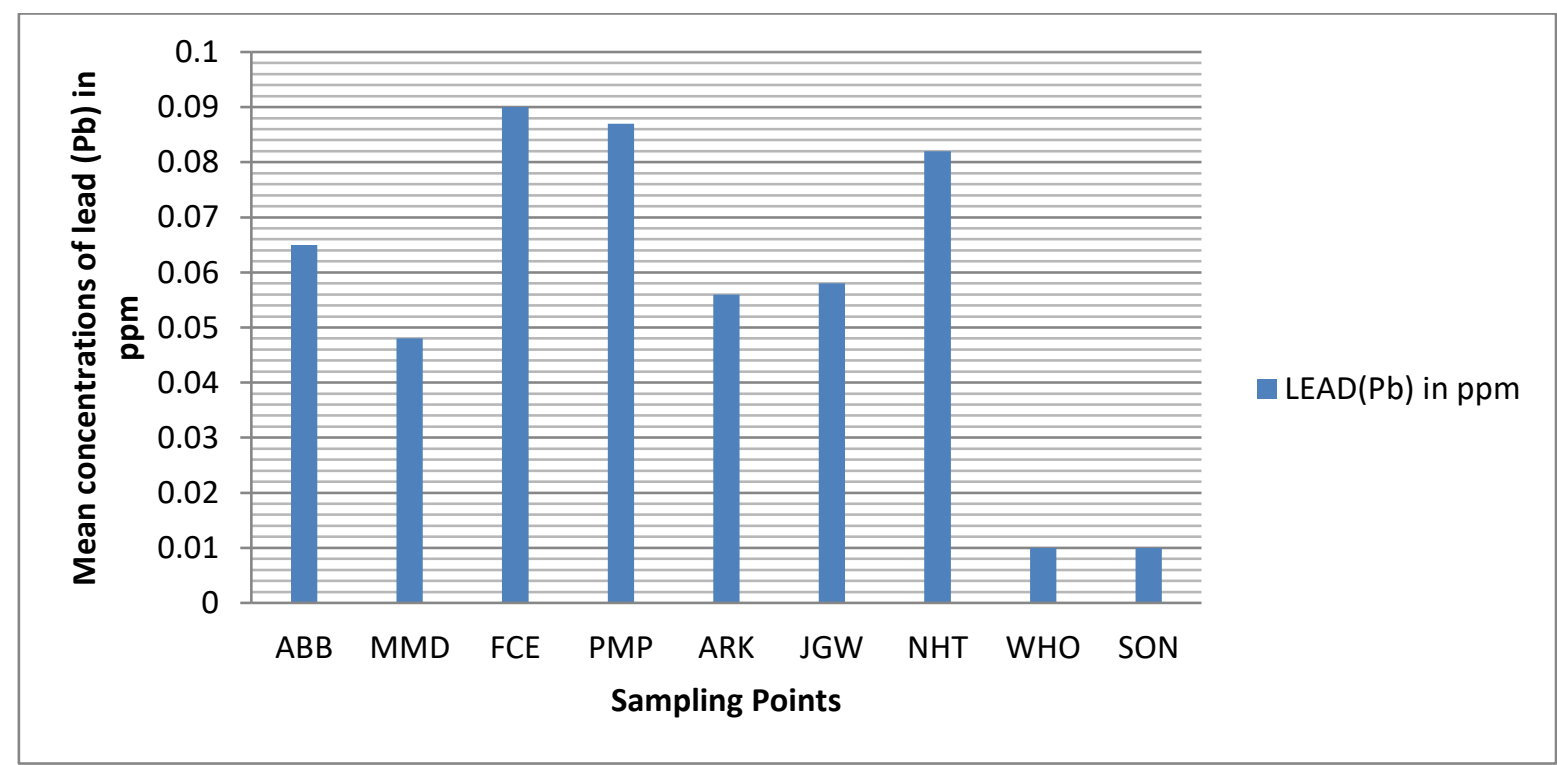

Figure 3: Mean concentrations of lead $(\mathrm{Pb})$ in Drinking Water of Potiskum Metropolitan. 


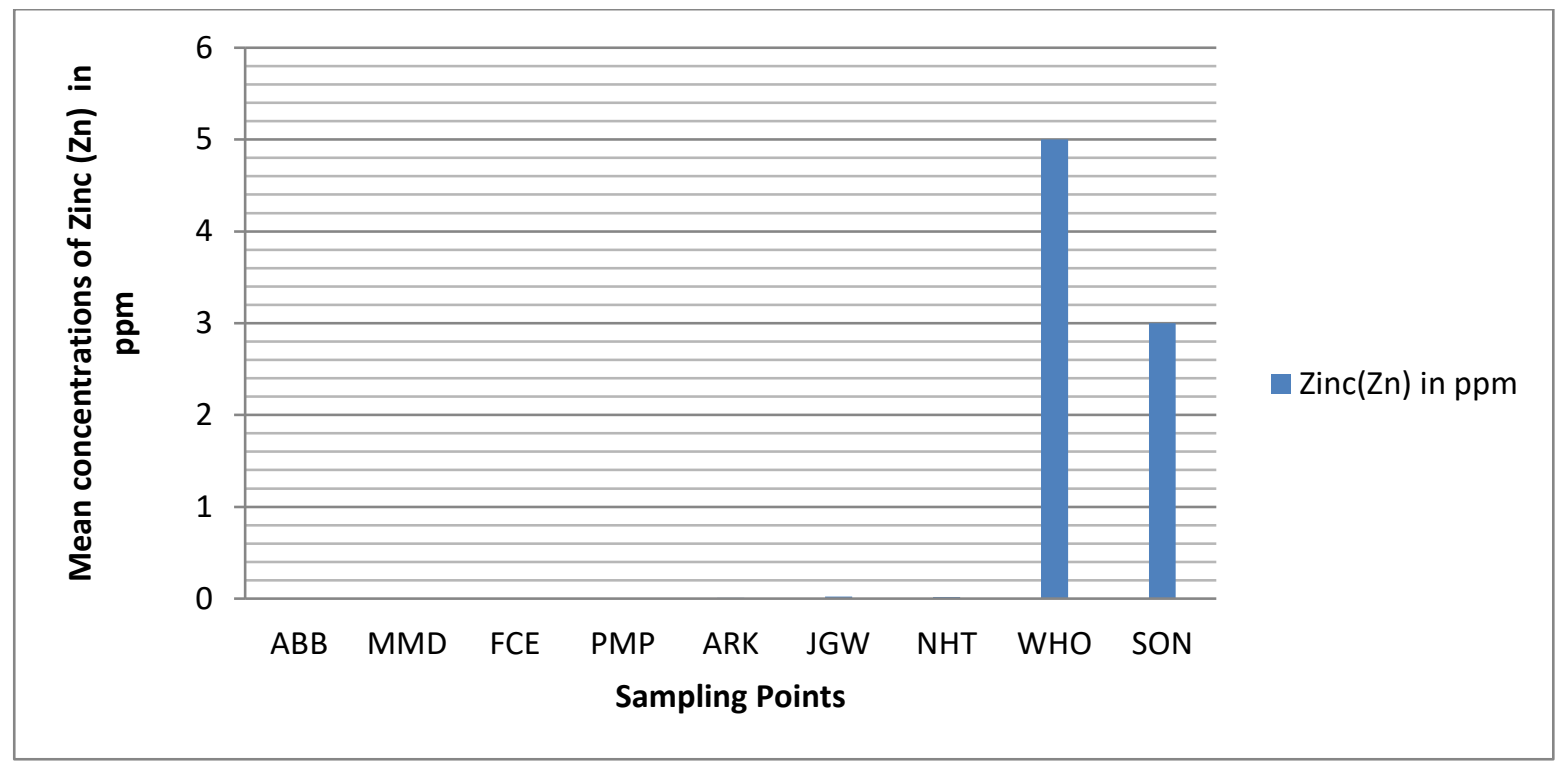

Figure 4: Mean concentrations of Zinc (Zinc) in Drinking Water of Potiskum Metropolitan.

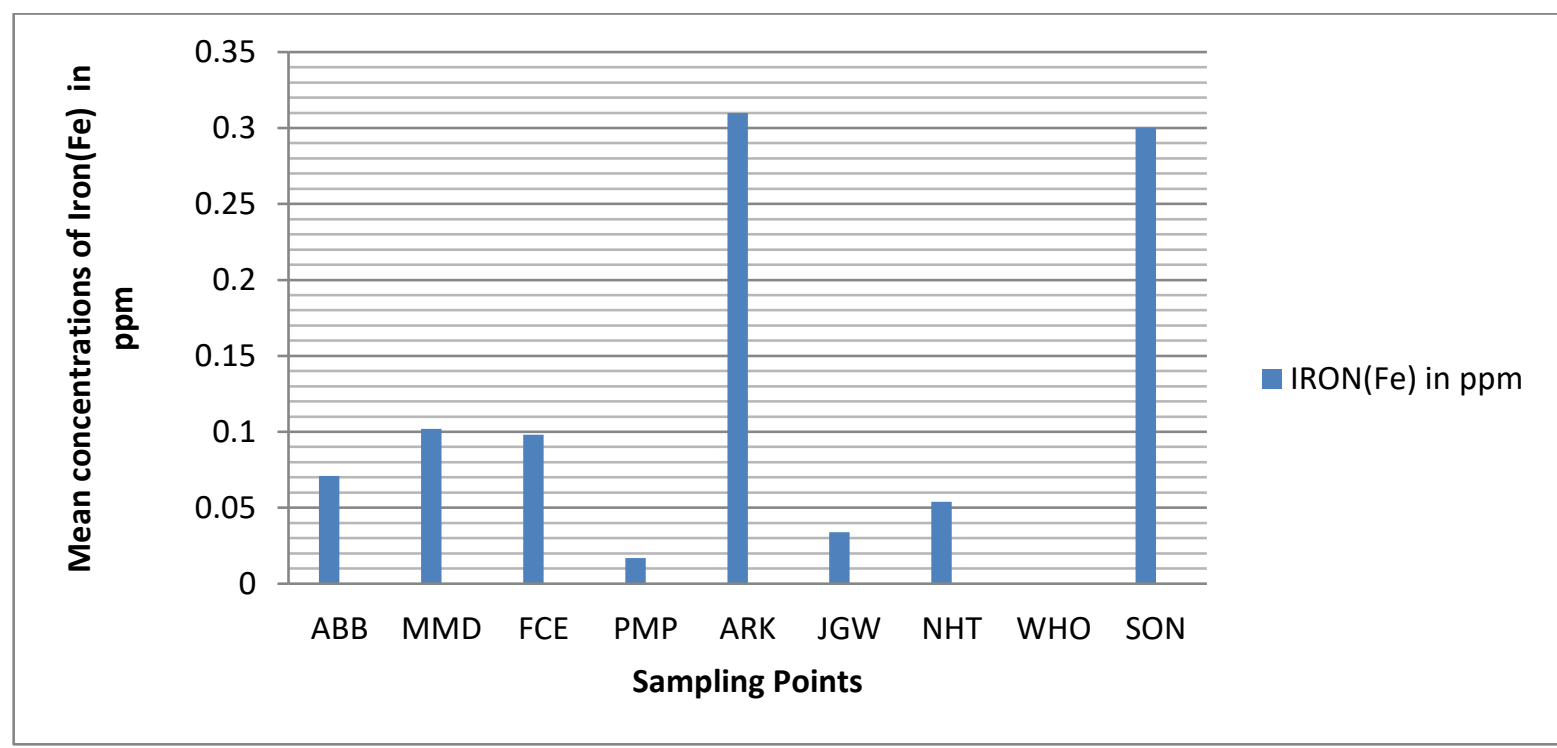

Figure 5: Mean concentrations of Iron (Fe) in Drinking Water of Potiskum Metropolitan.

\section{DISCUSSION}

This study was conducted to determine concentrations of heavy metals in the drinking water of the Potiskum metropolitan. The physic-chemical properties such as $\mathrm{pH}$, temperature and conductivity were measured in the field immediately and it can be seen from figure 1 and Table 4, the $\mathrm{pH}$ values recorded for this study ABB (pH =9.6), $\mathrm{PMP}(\mathrm{pH}=9.2)$ and $\mathrm{JGW}(\mathrm{pH}=8.8)$ all exceeded the recommended value set by SON and for an agency like World Health Organization, the report of $\mathrm{pH}$ is "not of health concerns at a level found in drinking water", also for conductivity measurement all measured values for this study were within the safety limit recommended value as indicated in Table 4 by SON even though is not considered as health concern at some level found in drinking water.

Cadmium (Cd): Table 2 and figure 2. Present the mean concentrations and standard deviation of cadmium in the drinking water of the Potiskum metropolitan. The results showed that the highest concentration of cadmium in drinking water was found in $\operatorname{FCE}(0.004 \pm 0.01 \mathrm{ppm})$ and the lowest in $\operatorname{ARK}(0.001 \pm 0.001 \mathrm{ppm})$. According to 
this study the mean concentration of cadmium $(\mathrm{Cd})$ found in ABB $(0.003 \pm 0.001 \mathrm{ppm})$ and PMP $(0.003 \pm 0.002$ $\mathrm{ppm}$ ) which is in line with the recommended value set by WHO/SON. However, the mean concentration of cadmium (Cd) in FCE $(0.004 \pm 0.001 \mathrm{ppm})$ was recorded above the recommended value set by $\mathrm{WHO} / \mathrm{SON}$ see Table 3 and figure 2. Also, for MMD $(0.002 \pm 0.001 \mathrm{ppm})$, ARK $(0.001 \pm 0.001 \mathrm{ppm}), \mathrm{JGW}(0.002 \pm 0.007 \mathrm{ppm})$, and NHT $(0.002 \pm 0.001 \mathrm{ppm})$ were observed below the recommended value set by WHO/ SON see Table 3 and figure 2. The result of the previous literature recorded by Abdullahi et al.[28] the value of cadmium in drinking water of all locations in Duste town Northwestern Nigeria were below the recommended value set by WHO/ SON. Another study by Casimer et al.[25] reported that cadmium concentrations in drinking water of Kaltungo Gombe were found above the recommended value set by WHO. There are many side effects of cadmium toxicity to human health such as; kidney toxicity, carcinogenic diseases (prostate cancer, etc.), and effects on bone rickets /osteomalacia, resulting in abnormal calcium homeostasis [29, 30]. These served as a signal to the people living in an area whose cadmium level is above the recommended value like FCE for this study.

Lead (Pb): From Table 2 and figure 3: It can be seen that the highest mean concentration of lead in Drinking water of Potiskum metropolitan was found in FCE $(0.090 \pm 0.012 \mathrm{ppm})$ and the lowest mean concentration was found in MMD (0.048 $\pm 0.015 \mathrm{ppm})$. Also, it can be observed that all collected samples of drinking water from sampling points in Potiskum metropolitan were recorded above the recommended value set by WHO / SON that is $(0.01 \mathrm{ppm})$ this is unsafe for human consumption and the major sources that cause these contaminants in the study areas is water reticulation system. According to some studies, leaching household plumbing is the main source of lead in drinking water. However, in some situation lead also enter drinking water via erosion of natural deposits in the earth crust as reported by [17, 26, 31]. These studies refer that the people of Potiskum may have diseases caused by lead such as cancer and cases of kidney problems and high blood pressure for adult were reported $[16,18,26]$. The high contaminates of lead in drinking water of these studied areas can also affect the intelligent quotient (I.Q) of the developing babies among pregnant mothers. Another study by Abdullahi et al. [28] observed the lead concentrations in drinking water of most of the sampling areas in Duste town northwestern Nigeria were below the recommended value set by WHO/ SON which is below the values in our finding for this study.

Zinc (Zn): Table 2 and figure 4 present the mean concentrations and standard deviation of zinc ( $\mathrm{Zn}$ ) in the drinking water of the Potiskum metropolitan. The highest mean concentration of zinc was recorded in JGW $(0.024 \pm 0.026 \mathrm{ppm})$ and the lowest was recorded in PMP $(0.002 \pm 0.001 \mathrm{ppm})$. All sampling points recorded the mean concentrations of zinc in their drinking water below the recommended value set by WHO/SON see Table 3. This indicates that people living in selected areas of this study are safe from contaminants of zinc metals in their drinking water and there are harmless from carcinogenic diseases like sarcoma, fever, etc. However, a similar analytical study of assessment of heavy metal pollution from river Ganga in West Bengal by Kar et al. [32] recorded the zinc level below the recommended value set by WHO.

Iron (Fe): Table 2 and Figure 5 present the mean concentrations and standard deviation of zinc in the drinking water of the Potiskum metropolitan. It can be seen that the highest mean concentration of iron in drinking water of the Potiskum metropolitan was observed in ARK $(0.310 \pm 0.063 \mathrm{ppm})$ and the lowest was observed in PMP $(0.017 \pm 0.027 \mathrm{ppm})$. However, the concentration of iron in drinking water of ARK slightly exceeded the recommended value set by SON see table 3. However, WHO [5] report indicated that the concentration of iron is "not of health concerns at a level found in drinking water". Moreover, the mean concentrations of iron in drinking water of PMP, ABB, FCE, MMD, JGW, and NHT were all recorded below the recommended value set by SON. Iron may be found in drinking water due to the use of iron coagulants or corrosion of steel and iron pipes in the distribution system, they can also stain laundry and plumbing pipes at level $0.3 \mathrm{mg} / \mathrm{L}$ and a level below $0.3 \mathrm{mg} / \mathrm{L}$ iron may display color and turbidity [5]). From all indications, this study revealed that the people of Potiskum metropolitan selected for this study mostly used polyethylene pipes wiring system and their drinking water is safe from contamination of iron except in the ARK area. A similar analytical study by Kantoma et al. [33] recorded the iron concentrations in drinking water of Kauru town of Kaduna state of northern Nigeria below the recommended value set by WHO. 


\section{CONCLUSION}

In this study, the concentration of lead, cadmium, zinc, and iron in drinking water of Potiskum metropolitan were measured using Atomic Absorption Spectrometer. meanwhile, the physic-chemical properties of the water samples such as $\mathrm{pH}$, conductivity, and temperature were determined for sample locations ABB, PMP, and JGW were observed above the recommended value set by SON and the result for Conductivities of the same locations were below the limit value set by SON. However, the results obtained for the heavy metals, the highest concentrations of cadmium and lead were found in sample location FCE. The highest concentrations of Zinc were observed in sample location JGW and finally, the highest concentrations of iron were found in sample location ARK area of Potiskum metropolitan. All the heavy metals reported in this study were recorded above the recommended values except for zinc which found to be below the recommended value set by WHO and SON. Therefore, the result of this study would serve as based line data for further studies and safety regulations by the authorities in addressing the issues of contamination in the drinking water of Potiskum metropolitan and beyond.

\section{CONFLICT OF INTERESTS}

The authors have declared that there is no conflict of interest.

\section{ACKNOWLEDGMENT}

The authors acknowledged the financial support of the Nigerian Tertiary Education Trust Fund (TETFUND) via Institutional Based Research (IBR) grand through the Federal College of Education (Tech) Potiskum, Yobe State. Moreover, the authors appreciate the staff of the scientific laboratory of the National Research Institute for Chemical Technology (NARICT) Zaria, for their analytical and technical supports.

\section{REFERENCES}

[1] Van Nostrand, (1964). International Encyclopedia of Chemical Science, Van Nostrand, New Jersey.

[2] Duffus, J., H (2002): "HEAVY METALS” A MEANINGLESS TERM (IUPAC Technical Report), Pure Appl. Chem., Vol. 74, No. 5, pp. 793-807.

[3] Feitelson, E., (2012): What is water? A normative perspective, Water Policy 14, 52-6. DOI:10.2166/wp.2012.003

[4] United Nations Children's Fund (1999): Water, Environment and Sanitation Technical Guidelines Series - No. 2: water handbook. New York: UNICEF Agency: UNICEF

[5]WHO (2017): Guidelines for drinking-water quality: fourth edition incorporating the first addendum, Geneva: World Health Organization; License: CC BY-NC-SA 3.0 IGO.

[6]WHO (2003) Zinc in drinking-water. Background document for preparation of WHO Guidelines for drinking-water quality. Geneva, World Health Organization (WHO/SDE/WSH/03.04/17).

[7]Yi, Y., Wang, Z., Zhang, K., Yu, G., Duan, X., (2008).Sediment pollution and its effect on fish through the food chain in the Yangtze River. International Journal of Sedimentary Research 23, 338-347.

[8]Jabeen, F., and Chaudhry, A.S., (2010). Monitoring trace metals in different tissues of Cyprinus carpio from the Indus River in Pakistan. Environmental Monitoring and Assessment 170, 645-656. http://dx.doi.org/10.1007/s10661009-1263-4.

[9]Alkan, N., Aktas, M., Gedik, K. (2012). Comparison of metal accumulation in fish species from the southeastern Black Sea, Bulletin of Environmental Contamination and Toxicology 88, 807-812.

[10]Malik, Q., A, and Khan, M. S. (2016): Effect on Human Health due to Drinking Water Contaminated with Heavy Metals, Journal of Pollution Effects \& Control 5(1). DOI: 10.4172/2375-4397.1000179

[11]Elinder C. G. Zinc. In: Friberg L, Nordberg GF, Vouk VB, eds. (1986): Handbook on the toxicology of metals, 2 nd ed. Amsterdam, Elsevier Science Publishers, 664-679.

[12]Tchocenwon, P. B., Yedjou, C. G., Patlolla, A. K., and Sutton, D. J. (2014): Heavy Metals Toxicity and the Environment, NIH Public Access, 101: 133-164.doi:10.1007/978-3-7643-8340-4_6.

[13]Baselt, RC.; Cravey, RH. (1995): Disposition of Toxic Drugs and Chemicals in Man. 4th Edn. Chicago, IL: Year Book Medical Publishers; p. 105-107.

[14]International Agency for Research on Cancer (IARC), (1993): Monographs - Cadmium. Lyon, France.

[15]Health Canada, (2019): Cadmium in Drinking Water: Guideline Technical Document for Public Consultation, Canada. 
[16]Oregon Health Authority (2016): lead and drinking water: Oregon Health Authority, OHA 8331

[17]ATSDR.Toxicological profile for lead. www.atsdr.cdc.gov/toxprofiles/tp13.pdf (2007).

[18]International Agency for Research on Cancer (IARC), (1987): In IARC Monographs on the Evaluation of Carcinogenic Risks to Humans.1(42). Lyons, France: IARC; Overall Evaluation of Carcinogenicity: An updating of Monographs; p. 230-232.

[19]Morais, S., Costa., F. G., and Pereira., M. L. (2014): Heavy Metals and Human Health, Environmental Health Emerging Issues and Practice.

[20]Elhamili, A., Abokhshim, A., Elaroud, K. and Elbaruni, S., (2016): Determination of Heavy Metals in Tap and Underground Water Using Atomic Absorption Spectrometry, Journal of Chemical and Pharmaceutical Research, 8(10), 108-111. www.jocpr.com

[21]Ogoyi, D. O., Mwita, C.J., Nguu E.K. and Shiundu, P.M., (2011): Determination of Heavy Metal Content in Water, Sediment and Microalgae from Lake Victoria, East Africa, The Open Environmental Engineering Journal, 4, 156161.

[22]Ramchander, J., Rajitha, B., Sunitha, G., Praveen, E., Anjaneyulu, A., Sunitha, J., and Rao., S. (2015): Quantitative Determination of Heavy Metals in the Water Samples of Four Areas of Hyderabad in Telangana State, Journal of Applied Chemistry (IOSR-JAC), 8, PP 18-19 www.iosrjournals.org

[23]Townsend., A., T., Sullivan, J. O., Featherstone, A. M., Butter, E. V., and Mackey, D. J. (2001): Application of ICPSMS, GF-AAS, and HG-AFS to the analysis of water and sediment samples from a temperate stratified estuary, Journal of Environmental Monitoring, 3,113-120. DOI: 10.1039/b008172h

[24]Nazir, R., Khan, M., Masab, M., Rehman, H., Rauf, N., Shahab, S., Ameer, N., Sajed, M., Ullah, M., Rafeeq, M., Shaheen., Z. (2015): Accumulation of Heavy Metals (Ni, Cu, Cd, Cr, Pb, Zn, Fe) in the soil, water and plants, and analysis of Physico-chemical parameters of soil and water Collected from Tanda Dam Kohat. J. Pharm. Sci. \& Res. 7(3), 89-97.

[25]Casimir E. G, George I. N., Elaoyi D. P., James D. H., Lamis A. M., (2015): Heavy Metals (Cd, Cu, Fe, Mn, and Zn,) Assessment of Groundwater, In Kaltungo LGA, Gombe State, Nigeria, International Journal of Science and Technology 4 (2).

[26]USEPA (2009): National Primary Drinking Water Regulations, EPA 816-F-09-004

[27]Standard Organization Nigeria (2015); Nigerian Standard Drinking Water Quality. ICS 13.060.20. Abuja Nigeria.

[28]Abdullahi, S., Ndikilar, C.E., Suleiman, A.B., and Hafeez, Y. H.(2016): Evaluation of Heavy Metal Concentration in Drinking Water Collected from Local Wells and Boreholes of Dutse Town, North West, Nigeria, Advances in Physics Theories and Applications. Vol.51,www.iiste.org.

[29]WHO (1992). Environmental health criteria No. 134. Cadmium. International Programme on Chemical Safety, World Health Organization. Geneva, Switzerland. Available at: www.inchem.org/documents/ehc/ehc/ehc134.htm

[30]JECFA (2011). Safety evaluation of certain food additives and contaminants. Report on the seventy-third meeting of the Joint FAO/WHO Expert Committee on Food Additives (JECFA). WHO Food Additive Series, 64: $305-380$.

[31]CDC. Lead: Water. www.cdc.gov/nceh/lead/tips/water.htm (2013).

[32]Kar D., Sur., P, Mandal S. K., Saha., T., and Kole., R.K (2008): Assessment of heavy metal pollution in surface water, International J., Environ Sci. Tech. 5(1), 119-124.

[33]Kantoma, D., Yusuf., J and Bidam., M.Y (2017): Assessment of Heavy Metals Concentration In Drinking Water Samples From Selected Areas Of Kauru Local Government Area Of Kaduna State, Nigeria, Bayero Journal of Pure and Applied Sciences, 10(1): 509 - 515 ISSN 2006 - 6996. 